\title{
Artikel
}

\section{De uitzondering bevestigd: het ne bis in idem-beginsel in recente rechtspraak van de Hoge Raad in het licht van de ratio van het ne bis in idem-beginsel en vanuit Europees perspectief}

Mr. W. (Willemijn) Albers en mr. T.M. (Tessa) de Groot*

\section{NTS 2020/7}

\section{Inleiding}

Het ne bis in idem-beginsel, dat bescherming biedt tegen het voor een tweede maal worden vervolgd en bestraft voor hetzelfde feit, heeft oude wortels en is vrijwel zo oud als het strafrecht zelf. ${ }^{1}$ Dat wil echter niet zeggen dat het beginsel een slapend bestaan leidt. Integendeel. Zowel in internationale als nationale rechtspraak en literatuur kan het rekenen op grote belangstelling en discussie. Daarbij gaat natuurlijk de meeste aandacht uit naar de grenzen van het beginsel. Zeker in een tijd waarin het (punitief) bestuursrecht aan een opmars bezig is en de mogelijkheden om laakbaar gedrag van burgers te

Mr. W. Albers is docent Straf(proces)recht bij het Willem Pompe Instituut voor Strafrechtswetenschappen aan de Universiteit Utrecht. Mr. T.M. de Groot is wetenschappelijk medewerker bij de Hoge Raad der Nederlanden. Deze bijdrage is op persoonlijke titel geschreven.

1. W.F. van Hattum, 'Non bis in idem of de schoonheid van de rechtsgeschiedenis', Ars Aequi 2013, p. 315-316. Van Hattum bepleit een terugkeer naar de oude formulering 'non' bis in idem, omdat dit sterker weergeeft dat het een verbod betreft in plaats van een aansporing of wens (p. 314-315). normeren ruimer worden, doet de vraag naar de reikwijdte van het ne bis in idem-beginsel zich steeds vaker voor. De uitleg die wordt gegeven aan de kernbegrippen bis (tweede vervolging) en idem (hetzelfde feit) is daarbij bepalend.

Dit artikel beoogt de reikwijdte van het ne bis in idembeginsel nader te onderzoeken. Daartoe zal de rechtspraak van de Hoge Raad na het welbekende arrest inzake het alcoholslotprogramma (hierna: het Alcoholslotprogramma-arrest $)^{2}$ worden besproken. Niet alleen in het kader van verkeersdelicten, zoals bij het samengaan van een strafvervolging met de oplegging van een Educatieve Maatregel Alcohol en Verkeer, de verplichting tot deelname aan een geschiktheidsonderzoek naar de rijvaardigheid of de (van rechtswege) ongeldigverklaring van het rijbewijs, ${ }^{3}$ maar ook bij de samenloop van een civiel- en strafrechtelijk traject ${ }^{4}$ is door of namens de verdachte veelvuldig een beroep gedaan op het Alcoholslotprogramma-arrest. De arresten die naar aanleiding daarvan zijn gewezen staan centraal in deze bijdrage. Bij de bespreking hiervan zal de focus liggen op de uitleg

2. HR 3 maart 2015, ECLI:NL:HR:2015:434, NJ 2015/256 m.nt. Keulen.

3. Zie bijv. HR 3 november 2015, ECLI:NL:HR:2015:3205, NJ 2016/72; HR 16 januari 2018, ECLI:NL:HR:2018:23, NJ 2018/64; HR 26 juni 2018, ECLI:NL:HR:2018:1014，NJ 2018/299; HR 2 oktober 2018, ECLI:NL:HR:2018:1818， NJ 2018/403; HR 18 december 2018, ECLI:NL:HR:2018:2350, NJ 2019/75.

4. HR 13 november 2018, ECLI:NL:HR:2018:2017, NJ 2019/74 m.nt. Reijntjes. 
die de Hoge Raad geeft aan het begrip 'bis' (tweede vervolging), nu het bij samenloop van enerzijds een strafrechtelijk en anderzijds een bestuursrechtelijk dan wel civielrechtelijk traject vooral draait om de vraag of dit bestuursrechtelijke of civielrechtelijke traject kan worden aangemerkt als een vervolging.

De structuur van deze bijdrage is als volgt. Allereerst wordt in paragraaf 2 kort stilgestaan bij de ratio van het ne bis in idem-beginsel. Vervolgens zal in paragraaf 3 voor een goed begrip van de materie het juridisch kader vanuit nationaal en Europees perspectief worden geschetst. ${ }^{5}$ Ook wordt in deze paragraaf het Alcoholslotprogramma-arrest besproken. In paragraaf 4 wordt de rechtspraak van de Hoge Raad die is gewezen na dit arrest besproken. Uit deze paragraaf zal blijken dat het Alcoholslotprogramma-arrest een uitzonderingspositie inneemt. In paragraaf 5 wordt de besproken rechtspraak beschouwd en gewaardeerd in het licht van de ratio van het ne bis in idem-beginsel en vanuit Europees perspectief. In paragraaf 6 komen wij ten slotte tot een afronding.

\section{De ratio van het ne bis in idem-beginsel}

De ratio van het ne bis in idem-beginsel is meervoudig. Het gaat in de eerste plaats om het voorkomen van meervoudige aansprakelijkstelling en bestraffing vanuit de idee van proportionaliteit van de straf. ${ }^{6}$ Dit is de materiële grondslag. Daarnaast strekt het processuele aspect van het beginsel ter bescherming van een persoon tegen herhaaldelijke vervolging. Iemand staat immers 'met heel zijn wezen' terecht ${ }^{7}$ en mag niet nodeloos worden gekweld door in een strafprocedure te worden betrokken voor hetzelfde feit (nemo debet bis vexari). ${ }^{8} \mathrm{Dit}$ processuele aspect is met name relevant indien de eerste

5. Het gaat de omvang deze bijdrage te buiten om alle internationale en Europese bepalingen waarin het ne bis in idem-beginsel is neergelegd te bespreken, maar vgl. volledigheidshalve art. 54 SUO in het kader van de Schengenlanden. Een belangrijke beperking van de werkingssfeer van dit artikel betreft het feit dat de tenuitvoerlegging van de opgelegde straf lopend of finaal dient te zijn. Zie voorts art. 3(2) KB EAB, op basis waarvan een eerdere onherroepelijke berechting voor dezelfde feiten een verplichte grond oplevert om overlevering van een opgeëist persoon te weigeren. Art. 50 van het Handvest van de Europese Unie biedt bescherming tegen dubbele berechting en/of bestraffing binnen deze Unie. Zie in het kader van de Raad van Europa art. 4 lid 1 Zevende Protocol EVRM. Vgl. ten slotte in internationaal verband art. 14 lid 7 IVBPR.

6. W.F. van Hattum, 'Non bis in idem of de schoonheid van de rechtsgeschiedenis', Ars Aequi 2013, p. 315; J. de Hullu, Materieel Strafrecht, Deventer: Wolters Kluwer 2018, p. 546

7. Vrij naar C. Kelk, 'De rechter en de kunst van het luisteren', in: H. Moerland e.a. (red.), De menselijke maat: opstellen ter gelegenheid van het afscheid van G.P. Hoefnagels, Arnhem: Gouda Quint 1992, p. 35.

8. De herziening ten nadele wordt beschouwd als een inbreuk op dit aspect van het ne bis in idem-beginsel. Zie daarover bijv. F.A. te Water Mulder, 'Herziening ten nadele van de vrijgesprokene: een inbreuk op het ne-bis-in-idembeginsel', DD 2008/50. vervolging niet tot aansprakelijkstelling heeft geleid. ${ }^{9}$ Voorts kan worden gewezen op de rechtszekerheid: men moet op een gegeven moment weer kunnen deelnemen aan het dagelijks leven zonder zwaard van Damocles boven het hoofd. ${ }^{10}$ Verdachten moeten erop kunnen vertrouwen dat, wanneer zij rechtmatig zijn vervolgd en berecht, de zaak ten einde is. Voorgaande grondgedachten zien primair op de bescherming van het individu tegen de overheid. Daarnaast kan gewezen worden op het gezag van de rechtspraak als belangrijke grondslag van het ne bis in idem-beginsel. ${ }^{11}$ Een onherroepelijke beslissing van de strafrechter moet worden gerespecteerd en is finaal (res iudicata). In het belang van de rechtszekerheid mag deze niet steeds opnieuw ter discussie worden gesteld. Eens moet per slot van rekening een einde komen aan het geschil (lites finiri oportet). ${ }^{12}$

\section{Het juridisch kader}

\subsection{Artikel 68 lid $1 \mathrm{Sr}$}

Artikel 68 lid $1 \mathrm{Sr}$ verwoordt het ne bis in idem-beginsel voor de Nederlandse strafrechtspleging en bepaalt dat niemand andermaal kan worden vervolgd wegens een feit waarover te zijnen aanzien door de Nederlandse rechter onherroepelijk is beslist. Indien een verdachte onherroepelijk is vrijgesproken, veroordeeld of ontslagen van alle rechtsvervolging door de strafrechter, staat deze bepaling eraan in de weg dezelfde verdachte wegens hetzelfde feit nogmaals voor de rechter te brengen en te berechten. Voornoemde einduitspraken betreffen de materiële einduitspraken in de zin van artikel 350 jo. 352 Sv. Een onherroepelijke formele einduitspraak in de zin van artikel 349 lid 1 Sv zal evenwel niet in de weg staan aan een tweede vervolging. ${ }^{13}$

Niet alleen de strafrechter, ook het Openbaar Ministerie en bepaalde bestuursorganen zijn uitgerust met mogelijkheden om bestraffende sancties op te leggen. Waar het Openbaar Ministerie gebruik maakt van het opleggen van strafbeschikkingen zoals bedoeld in artikel 257a Sv, hebben bestuursorganen de mogelijkheid tot aansprakelijkstelling door onder andere de bestuurlijke boete. Artikel 68 lid $1 \mathrm{Sr}$ beschermt de verdachte die op

9. J. de Hullu, Materieel Strafrecht, Deventer: Wolters Kluwer 2018, p. 546.

10. Vgl. in die trant ook toenmalig minister van Justitie Van Maanen: 'Men erkent dat er gevallen kunnen bestaan, waarin de stellige bewijzen van schuld, na de teregstelling kunnen worden ontdekt; doch in die zeldzame gevallen, is het beter den misdadiger ongestraft te laten, dan eene zoodanige wijde deur te openen, waardoor iemand die definitievelijk is teregt gesteld, vele jaren in ongerustheid zoude doorbrengen' (Memorie van beantwoording, 2 februari 1830, Bijl. Hand. der Staten-Generaal 1829-1830, V, 27, p. 135).

11. F.A. te Water Mulder, 'Herziening ten nadele van de vrijgesprokene: een inbreuk op het ne-bis-in-idembeginsel', DD 2008/50, p. 721.

12. J. de Hullu, Materieel strafrecht, Deventer: Wolters Kluwer 2018, p. 546.

13. J. de Hullu, Materieel strafrecht, Deventer: Wolters Kluwer 2018, p. 547. 
een dergelijke wijze aansprakelijk is gesteld niet tegen een tweede vervolging voor hetzelfde feit, omdat het geen onherroepelijke uitspraken van de strafrechter zijn. ${ }^{14}$ Indien de verdachte voor hetzelfde feit wordt beoordeeld en gesanctioneerd in zowel een strafrechtelijke als een civiel- ${ }^{15}$ dan wel bestuursrechtelijke ${ }^{16}$ procedure, biedt artikel 68 lid $1 \mathrm{Sr}$ om diezelfde reden geen bescherming.

Hoe ver de bescherming van artikel 68 lid $1 \mathrm{Sr}$ reikt, is zoals gezegd afhankelijk van wat men verstaat onder de begrippen 'hetzelfde feit' (idem) en 'tweede vervolging' (bis). Hoe sneller een gedraging wordt aangemerkt als 'hetzelfde feit' en een procedure als een 'tweede vervolging', hoe eerder artikel 68 lid $1 \mathrm{Sr}$ bescherming biedt. Zoals uit het voorgaande volgt, beschermt artikel 68 lid $1 \mathrm{Sr}$ niet tegen externe samenloop van procedures, oftewel een 'tweede vervolging' die buiten de strafrechtelijke sfeer plaatsheeft. Dan is met andere woorden geen sprake van een 'bis'. Voor het feitsbegrip, ofwel de 'idem', neemt de Hoge Raad zowel de juridische aard van de feiten (waarbij de beschermde rechtsgoederen en de strafmaxima die op de onderscheiden feiten zijn gesteld een rol spelen) als de feitelijke aspecten van de gedraging van de verdachte (de aard en de kennelijke strekking van de gedragingen en de tijd waarop, de plaats waar en de omstandigheden waaronder zij zijn verricht) in aanmerking. ${ }^{17}$

\subsection{Europees Verdrag voor de Rechten van de Mens}

Artikel 4 van het Zevende Protocol bij het Europees Verdrag voor de Rechten van de Mens (hierna: 4P7 EVRM) bevat 'the right not to be tried or punished twice'. Op het eerste gezicht is de relevantie van deze bepaling voor de Nederlandse rechtsorde beperkt. Nederland heeft het Zevende Protocol immers niet geratificeerd. De rechtspraak van het Europees Hof voor de Rechten van de Mens (hierna: EHRM) is echter wel van groot belang voor de gedachtevorming over het ne bis in idembeginsel. De Hoge Raad heeft in zijn arresten meermaals verwezen naar deze bepaling en de jurisprudentie van het EHRM inzake het ne bis in idem-beginsel. ${ }^{18}$ De meerwaarde van artikel 4P7 EVRM ten opzichte van artikel 68 lid $1 \mathrm{Sr}$ is primair gelegen in de ruimere reikwijdte. Waar artikel 68 lid $1 \mathrm{Sr}$ enkel ziet op uitspraken

14. Art. 5:44 Awb en art. 243 lid 2 Sv bieden bescherming tegen de samenloop van een bestuurlijke boete en strafvervolging (una via). Art. 255a lid $1 \mathrm{~Sv}$ bepaalt dat de verdachte tegen wie een strafbeschikking is uitgevaardigd die volledig ten uitvoer is gelegd, niet voor hetzelfde feit opnieuw in rechten kan worden betrokken.

15. Vgl. HR 2 december 1952, ECLI:NL:HR:1952:177, NJ 1953/132; HR 14 juni 2011, ECLI:NL:HR:2011:BP0287, NJ 2011/504 m.nt. Dommering.

16. Vgl. HR 5 december 2017, ECLI:NL:HR:2017:3062, NJ 2018/231 m.nt. Reijntjes; HR 12 december 2017, ECLI:NL:HR:2017:3122, NJ 2018/94 m.nt. Reijntjes; HR 16 januari 2018, ECLI:NL:HR:2018:23, NJ 2018/64.

17. HR 1 februari 2011, ECLI:NL:HR:2011:BM9102, NJ 2011/394 m.nt. Buruma, r.o. 2.9.1.-2.9.2

18. Vgl. bijv. HR 1 februari 2011, ECLI:NL:HR:2011:BM9102, NJ 2011/394 m.nt. Buruma; HR 3 maart 2015, ECLI:NL:HR:2015:434, NJ 2015/256 m.nt. Keulen en HR 12 juni 2018, ECLI:NL:HR:2018:901, NJ 2018/388 m.nt. Reijntjes. van de strafrechter en daarmee vergelijkbare afdoeningen binnen de strafrechtelijke sfeer, biedt artikel 4P7 EVRM ook bescherming tegen het samengaan van een strafrechtelijke en (bijvoorbeeld) bestuursrechtelijke procedure, indien en zolang deze laatste procedure naar objectieve maatstaven te kwalificeren is als een criminal charge in de zin van artikel 6 EVRM. ${ }^{19}$ Deze maatstaven worden de 'Engel-criteria' genoemd, naar het gelijknamige arrest. ${ }^{20}$ In de eerste plaats is de classificatie van de overtreding in het nationale recht van belang. Voorts worden de aard van de overtreding en de aard en zwaarte van de sanctie die naar aanleiding van de overtreding kan worden opgelegd in aanmerking genomen. ${ }^{21}$ Indien op grond van deze criteria een procedure kan worden aangemerkt als een criminal charge, biedt artikel 4P7 EVRM bescherming tegen externe samenloop van afdoeningen. Dat is evenwel anders indien tussen de procedures een 'sufficiently close connection in substance and in time' bestaat, zoals bedoeld in het arrest A en B tegen Noorwegen. ${ }^{22}$ Of een dergelijke 'connection' zich voordoet wordt bepaald aan de hand van de volgende materiële factoren:

i. whether the different proceedings pursue complementary purposes and thus address, not only in abstracto but also in concreto, different aspects of the social misconduct involved;

ii. whether the duality of proceedings concerned is a foreseeable consequence, both in law and in practice, of the same impugned conduct (idem);

iii. whether the relevant sets of proceedings are conducted in such a manner as to avoid as far as possible any duplication in the collection as well as the assessment of the evidence, notably through adequate interaction between the various competent authorities to bring about that the establishment of facts in one set is also used in the other set;

iv. and, above all, whether the sanction imposed in the proceedings which become final first is taken into account in those which become final last, so as to prevent that the individual concerned is in the end made to bear an excessive burden, this latter risk being least likely to be present where there is in place an offsetting mechanism design-

19. EHRM 10 november 2009, nr. 14939/03 (Zolothukin/Rusland), $\S 52-56$.

20. EHRM 8 juni 1976, nrs. 5100/71, 5101/71, 5102/71 en 5370/72 (Engel e.a./Nederland).

21. De juridische classificatie van de feiten is niet doorslaggevend. Ook naar nationaal recht geclassificeerde bestuursrechtelijke feiten kunnen worden aangemerkt als een criminal charge. Het doel van het beginsel zou immers ondermijnd kunnen worden indien de juridische classificatie van de feiten wel van doorslaggevende betekenis zou zijn. Het tweede en laatste criterium worden over het algemeen in samenhang met elkaar beschouwd en getoetst.

22. EHRM 15 november 2016, nrs. 24130/11 en 29758/11 ( $A$ en B/Noorwegen), § 130-132. Zie ook EHRM 18 mei 2017, nr. 22007/11 (Jóhannesson e.a./IJsland) waar géén 'sufficiently close connection in substance and in time' werd aangenomen. 
ed to ensure that the overall amount of any penalties imposed is proportionate. ${ }^{23}$

Bovenstaande factoren lijken onderling enigszins gecompenseerd te kunnen worden en niet cumulatief te zijn, maar de procedures moeten zowel in substance als in time voldoende samenhang vertonen. ${ }^{24}$ Voor het aannemen van een voldoende nauwe samenhang in tijd is niet vereist dat de procedures volledig gelijktijdig plaatsvinden. ${ }^{25}$ Wel dienen ze zodanig geïntegreerd te zijn, dat zij een coherent geheel vormen. Daarbij benadrukt het EHRM dat de overheidsreactie als geheel proportioneel dient te zijn, door de sanctie die is opgelegd in de procedure die als eerste definitief wordt in aanmerking te nemen in de latere procedure. In die gevallen waarin sprake is van procedures met een 'sufficiently close connection in substance and in time' moeten de procedures worden beschouwd als één samenhangende reactie op een bepaalde overtreden norm en niet als een tweede procedure (bis). De bescherming van het ne bis in idembeginsel wordt daardoor beperkt, nu in wezen cumulatie van punitieve sancties in dergelijke gevallen wordt toegestaan.

Voor het idem-begrip hanteert het EHRM een feitelijke toets. ${ }^{26}$ Tweede vervolging of berechting is uitgesloten voor 'identical facts, or facts which are substantially the same'. ${ }^{27}$ De ratio van deze feitelijke benadering van het idem-begrip is een meeromvattende mensenrechtenbescherming. Een benadering waarbij de juridische kwalificatie van de onderliggende strafbaarstellingen een grote rol zou spelen werd door het EHRM te restrictief geacht, omdat lidstaten in dat geval de bescherming van artikel 4P7 EVRM kunnen omzeilen door bepaalde strafbaarstellingen buiten de nationale strafwet onder te brengen. $^{28}$

\subsection{Handvest van de grondrechten van de Europese Unie}

In artikel 50 van het Handvest van de grondrechten van de Europese Unie (hierna: Handvest) is het recht vervat om niet tweemaal voor hetzelfde delict te worden berecht of bestraft binnen de Europese Unie. Daarmee

24. EHRM 18 mei 2017, nr. 22007/11 (Jóhannesson e.a./IJsland), § 5055.

25. EHRM 15 november 2016, nrs. 24130/11 en 29758/11 ( $A$ en B/Noorwegen), § 134

26. Wij willen er volledigheidshalve op wijzen dat het EHRM in het kader van het idem-begrip ook ruimte open lijkt te laten voor een juridische toets door de delictsomschrijvingen van de nationale wetten ook in ogenschouw te nemen (vgl. EHRM 10 november 2009, nr. 14939/03 (Zolothukin/Rusland), § 97). Zie hierover uitgebreid F.C.W. de Graaf, 'Ne bis in idem. Twee keer hetzelfde in de rechtspraak van het Hof van Justitie van de Europese Unie en het Europees Hof voor de Rechten van de Mens', DD 2013/34, p. 380.

27. EHRM 10 november 2009, nr. 14939/03 (Zolothukin/Rusland), § 82 en 84.

28. EHRM 10 november 2009, nr. 14939/03 (Zolothukin/Rusland), § 81. Zie ook F.C.W. de Graaf, 'Ne bis in idem. Twee keer hetzelfde in de rechtspraak van het Hof van Justitie van de Europese Unie en het Europees Hof voor de Rechten van de Mens', DD 2013/34, p. 377. heeft het artikel een bredere werkingssfeer dan artikel 4P7 EVRM, dat alleen geldt binnen de rechtsmacht van één staat. Daarentegen beschermt artikel 50 Handvest, gelet op artikel 51 lid 1 Handvest, enkel tegen dubbele vervolging wanneer lidstaten Unierecht ten uitvoer brengen. Dat is een belangrijke beperking, die wij echter ook direct willen relativeren. Gezien de grote hoeveelheid wetgeving met herkomst uit Brussel brengen lidstaten geregeld (direct of indirect) Unierecht ten uitvoer. ${ }^{29}$ Daarmee is het potentiële toepassingsbereik van het Handvest groot. Het zelfstandige belang van de rechtspraak van het Hof van Justitie van de Europese Unie (hierna: HvJ EU) voor de waarborging van de mensenrechten kan dan ook niet genoeg worden benadrukt. ${ }^{30}$

Blijkens de toelichting op artikel 50 Handvest heeft het feitsbegrip (idem) dezelfde inhoud en reikwijdte als art. 4P7 EVRM in nationale situaties. ${ }^{31}$ Dit betekent dat, hoewel Nederland het Zevende Protocol bij het EVRM niet geratificeerd heeft, de uitleg die het EHRM aan het idem-begrip geeft over de band van artikel 50 Handvest toch de Nederlandse rechtsorde in sijpelt. In die gevallen waarin Unierecht ten uitvoer wordt gebracht, is de Nederlandse rechter verplicht de meer feitelijke benadering van de Europese hoven toe te passen. ${ }^{32}$

Ook voor wat betreft de bis is op twee punten sprake van een convergentie in de rechtspraak van beide Europese hoven. Cumulatie van een strafrechtelijke en (bijvoorbeeld) bestuursrechtelijke procedure is op grond van artikel 50 Handvest toegestaan indien de sanctie die wordt opgelegd in de bestuursrechtelijke procedure niet punitief van aard is. ${ }^{33}$ Het HvJ EU zoekt in verband met de vraag of een sanctie punitief is expliciet aansluiting bij de Engel-criteria. ${ }^{34}$ Een dergelijke convergentie is

29. J.W. Ouwerkerk, 'Het feitsbegrip bij ne bis in idem en eendaadse samenloop: Tussen nationale uitlegging en internationale verplichtingen', DD 2012, afl. 6, p. 498.

30. Zie hierover ook M.J.J.P. Luchtman, 'Transnationale rechtshandhaving in de EU en het ne bis in idem-beginsel', SEW 2011/6, p. 281 en J.A.W. Lensing, 'Grondrechten van de EU in de Nederlandse straf(proces)rechtelijke praktijk', Strafblad 2012, p. 25-26 en 31.

31. Toelichting ad artikel 50 Handvest, PbEU 14 december 2007, C303/17. In nationale situaties waarin art. 50 Handvest van toepassing is, wordt derhalve de (min of meer) feitelijke benadering van art. 4P7 EVRM toegepast. In transnationale situaties volgt het HvJ EU de feitelijke uitleg van art. 54 SUO. Zie bijv. HvJ EU 16 november 2010, ECLI:EU:C: 2010:683, C-261/09 (Mantello) (§ 39-40): 'de feiten zelf en een geheel van onlosmakelijk met elkaar verbonden concrete omstandigheden, ongeacht de juridische kwalificatie van deze feiten of het beschermde rechtsbelang'

32. Vgl. de conclusie van A-G Campos Sánchez-Bordona voor HvJ EU 20 maart 2018, ECLI:EU:C:2018:197, C-524/15 (Menci)

33. HvJ EU 26 februari 2013, ECLI:EU:C:2013:105, C-617/10 (Åkerberg Fransson).

34. Zie bijv. HvJ EU 5 juni 2012, ECLI:EU:C:2012:319, C-489/10 (Bonda), $\S 37$ en HvJ EU 26 februari 2013, ECLI:EU:C:2013:105, C-617/10 (Åkerberg Fransson), § 35 
ook te bemerken bij parallelle punitieve procedures. ${ }^{35}$ Het HvJ EU sluit in dat kader grotendeels aan bij het arrest van het EHRM inzake A en B tegen Noorwegen. ${ }^{36}$ Cumulatie van punitieve sancties is kort gezegd toegestaan indien (i) deze cumulatie kan worden gerechtvaardigd op grond van verschillende doelen van algemeen belang, waarbij beide sancties in elkaar aanvullende doelen moeten voorzien, (ii) regels bestaan waarmee voor onderlinge afstemming tussen de procedures kan worden gezorgd en (iii) de zwaarte van het geheel van de opgelegde sancties is beperkt tot het strikt noodzakelijke in verhouding tot de ernst van het delict. ${ }^{37}$ Het is met andere woorden van belang dat de nationale rechter in de hoofdzaak ervoor zorgdraagt dat de overheidsreactie als geheel niet disproportioneel uitvalt in verhouding tot het laakbare gedrag, door rekening te houden met de eerder opgelegde sanctie.

\subsection{De beginselen van een goede procesorde: het} Alcoholslotprogramma-arrest

In uitzonderlijke situaties kan ten slotte het ne bis in idem-beginsel als zodanig van toepassing zijn en kunnen de beginselen van een goede procesorde meebrengen dat het Openbaar Ministerie niet-ontvankelijk wordt verklaard in de vervolging wegens onverenigbaarheid van die vervolging met het ne bis in idem-beginsel. In HR 3 maart 2015, ECLI:NL:HR:2015:434, Nf 2015/256 m.nt. Keulen (Alcoholslotprogramma) ${ }^{38}$ was aan de verdachte door het Centraal Bureau voor de Rijvaardigheid (hierna: CBR) deelname aan het alcoholslotprogramma opgelegd wegens rijden onder invloed. Het Openbaar Ministerie startte een vervolging voor dezelfde gedraging (idem). ${ }^{39}$ De Hoge Raad stelde voorop dat artikel $68 \mathrm{Sr}$ op het onderhavige geval niet van toepassing was, nu geen sprake was van meerdere onherroepelijke beslissingen van de strafrechter. Ook de

35. Zie over de overeenkomsten en verschillen in de benadering van beide hoven uitgebreid: M.J. Vetzo, 'The Past, Present and Future of the Ne Bis In Idem Dialogue between the Court of Justice of the European Union and the European Court of Human Rights: The Cases of Menci, Garlsson and Di Puma', Review of European Administrative Law 2018, vol. 11, nr. 2, p. 55- 84 .

36. HvJ EU 20 maart 2018, ECLI:EU:C:2018:197, C-524/15 (Menci), § 60-64. Vgl. de andersluidende conclusie van A-G Campos SánchezBordona, die geen reden ziet het beschermingsniveau van Åkerberg Fransson in te perken door aan te sluiten bij A en B/Noorwegen (§ 69). Zie ook HvJ EU 20 maart 2018, ECLI:EU:C:2018:193, C-537/16 (Garlsson), HvJ EU 20 maart 2018, ECLI:EU:C:2018:192, C-596/16 (Di Puma) en C-597/16 (Zecca).

37. HvJ EU 20 maart 2018, ECLI:EU:C:2018:197, C-524/15 (Menci), § 63.

38. Dit arrest is in de literatuur uitgebreid becommentarieerd. Zie bijv. M.S. Groenhuijsen, 'Het alcoholslot op slot in het Nederlandse strafrecht en bestuursrecht', DD 2015/33, p. 335-342; O.S. Pluimer, 'De Hoge Raad over het ne bis in idem-beginsel ten aanzien van het alcoholslotprogramma: een rechtvaardig doch onbevredigend arrest', DD 2015/41, p. 405-426 en F.C.W. de Graaf, Meervoudige aansprakelijkstelling, Een analyse van rechtsfiguren die aansprakelijkstelling voor meer dan één strafbaar feit normeren, Den Haag: Boom juridisch 2018, p. 244-247.

39. De Hoge Raad overwoog in dat kader dat de aan de betrokkene verweten gedraging identiek was, te weten rijden onder invloed, terwijl de beschermde rechtsgoederen - het bevorderen van de verkeersveiligheid - in hoge mate vergelijkbaar zijn. Daarnaast kwamen de gevolgen voor de betrokkene van het opleggen van een alcoholslotprogramma en de van het instellen van een strafvervolging te verwachten strafrechtelijke sancties in hoge mate overeen (r.o. 4.3.2) internationale bepalingen inzake het ne bis in idembeginsel waren niet van toepassing, omdat het Zevende Protocol bij het EVRM door Nederland niet geratificeerd is en in het onderhavige geval ook geen sprake was van uitvoering van Unierecht. Om deze reden was de Hoge Raad in dit concrete geval genoodzaakt terug te vallen op de beginselen van een goede procesorde.

Hoewel het internationale kader niet direct van toepassing was, konden daaraan volgens de Hoge Raad wel elementen worden ontleend die van belang zijn voor de vraag of het ne bis in idem-beginsel in de weg staat aan strafrechtelijke vervolging. De Hoge Raad overwoog dat in internationaal verband niet zonder meer doorslaggevend is of de nationale wetgever een maatregel als bestuursrechtelijk of als strafrechtelijk heeft aangemerkt. $\mathrm{Nu}$ in het voorliggende geval een sterke gelijkenis bestond tussen de bestuursrechtelijke maatregel van het alcoholslotprogramma en de strafrechtelijke vervolging door het Openbaar Ministerie deed zich hier een 'uitzonderlijke - van andere gevallen waarin een bestuursrechtelijk en een strafrechtelijk traject samenlopen, afwijkende - situatie' voor die op gespannen voet stond met het aan artikel 68 lid $1 \mathrm{Sr}$ ten grondslag liggende ne bis in idem-beginsel. De Hoge Raad oordeelde dat de beginselen van een goede procesorde in dit geval meebrachten dat de inbreuk op het aan artikel 68 lid 1 ten grondslag liggende ne bis in idem-beginsel de nietontvankelijkheid van het Openbaar Ministerie tot gevolg had. Hoewel de Hoge Raad het niet met zoveel woorden overwoog, ${ }^{40}$ lijkt in dit oordeel besloten te liggen dat het alcoholslotprogramma moet worden beschouwd als een punitieve sanctie. Als dat anders zou zijn, zou immers het ne bis in idem-beginsel niet in de weg staan aan strafrechtelijke vervolging.

Dit roept de vraag op welke aan het alcoholslotprogramma verbonden voorwaarden het punitieve karakter van de sanctie teweegbrachten. De Hoge Raad overwoog in verband met de vraag of sprake is van 'hetzelfde feit' onder andere dat de gevolgen van het alcoholslotprogramma en de van het instellen van strafvervolging te verwachten sancties in hoge mate overeenkomen: beide kunnen leiden tot een ingrijpende beperking van de rijbevoegdheid en tot oplegging van een wezenlijke betalingsverplichting. Deelname aan het alcoholslotprogramma kost tussen de $€ 4.000$ en $€ 5$.000. Indien de betrokkene om financiële of andere redenen niet kan of wil deelnemen aan het alcoholslotprogramma, wordt zijn rijbewijs voor de duur van vijf jaren ongeldig verklaard. Daarmee dringt zich de gelijkenis met een forse boete en de ontzegging van de rijbevoegdheid op.

Ondanks de voorzichtige formulering van de Hoge Raad dat zich een 'uitzonderlijke (...) situatie' voordeed, is met name in verkeerszaken, maar ook bij samenloop van

40. Vgl. A-G Harteveld in zijn conclusie voor dit arrest, die aan de hand van de Engel-criteria expliciet de vraag beantwoordt of de procedure tot oplegging van deelname het alcoholslotprogramma moet worden beschouwd als een criminal charge in de zin van art. 6 EVRM (punt 8.31-8.42) 
een strafrechtelijke vervolging met bijvoorbeeld civielrechtelijke procedures, veelvuldig een beroep gedaan op het Alcoholslotprogramma-arrest. In de navolgende paragraaf bespreken wij enkele in het oog springende arresten die naar aanleiding daarvan zijn gewezen. ${ }^{41}$ In paragraaf 5 volgt vervolgens een algemene beschouwing en waardering van deze rechtspraak.

\section{Het ne bis in idem-beginsel in recente jurisprudentie van de Hoge Raad}

\subsection{Verkeerszaken}

Niet alleen de oplegging van het alcoholslotprogram$\mathrm{ma}^{42}$ als zodanig, maar ook schending van de voorwaarden van een reeds opgelegd alcoholslotprogramma kan vragen doen rijzen in verband met het ne bis in idembeginsel. In HR 2 oktober 2018, ECLI:NL:HR: 2018:1818, NF 2018/403 werd het rijbewijs van de verdachte, een deelnemer aan het alcoholslotprogramma, door het CBR ongeldig verklaard nadat hij als bestuurder was aangehouden in een auto die niet was voorzien van een alcoholslot. Daarnaast werd aan de verdachte een gevangenisstraf voor de duur van twee weken opgelegd wegens overtreding van artikel 9 lid 9 onder a WVW 1994 (rijden in een auto zonder alcoholslot). De verdediging betoogde, onder verwijzing naar het Alcoholslotprogramma-arrest, dat de strafrechtelijke vervolging in strijd was met het ne bis in idem-beginsel, maar de Hoge Raad ging hier niet in mee. Heel gek is dat niet. Waar het in dat arrest ging om het samengaan van een strafrechtelijke vervolging met de oplegging van de verplichting tot deelname aan het alcoholslotprogramma, draait het in het onderhavige geval om het samengaan van een strafrechtelijke vervolging wegens schending van artikel 9 lid 9 onder a WVW 1994 met de ongeldigverklaring van het rijbewijs. Het (reeds rechtsgeldig opgelegde) alcoholslotprogramma is hier aldus niet de opgelegde sanctie, maar de schending van de voorwaarden van het programma is de aanleiding voor

41. Vgl. naast de in deze bijdrage besproken jurisprudentie voorts o.a. HR 12 april 2016, ECLI:NL:HR:2016:613 en 615 voor de oplegging van een stadionverbod door de KNVB en het verbeuren van een geldboete aan de KNVB; HR 5 december 2017, ECLI:NL:HR:2017:3062, NJ 2018/231 en HR 14 mei 2019, ECLI:NL:HR:2019:711 voor een huisverbod respectievelijk locatieverbod en ten slotte HR 14 februari 2017, ECLI:NL:HR: 2017:241, NJ 2017/289; HR 31 oktober 2017, ECLI:NL:HR:2017:2796, NJ 2018/95 m.nt. Reijntjes; HR 12 december 2017, ECLI:NL:HR: 2017:3122, NJ 2018/94 m.nt. Reijntjes en HR 16 juni 2018, ECLI:NL:HR:2018:901, NJ 2018/388 m.nt. Reijntjes.

42. Het alcoholslotprogramma is overigens inmiddels afgeschaft. Zie Kamerstukken I/ 2016/17, 29398, 529, p. 2 ongeldigverklaring van het rijbewijs. ${ }^{43}$ Dat is niet problematisch in het licht van het ne bis in idem-beginsel, nu de ongeldigverklaring van een rijbewijs een bestuursrechtelijke maatregel - en dus geen punitieve sanctie is. ${ }^{44}$ Zoals A-G Bleichrodt ook aantekent in zijn conclusie voorafgaand aan dit arrest doet zich hier niet de uitzonderlijke situatie voor als bedoeld in het Alcoholslotprogramma-arrest, waarin twee procedures over een identiek verweten gedraging hun directe oorsprong vonden in hetzelfde feit met sterk gelijkende gevolgen, nu de ongeldigverklaring van het rijbewijs en de gevangenisstraf andersoortige sancties zijn. Ook wijst hij erop dat het gaat om een voorzienbare cumulatie van procedures, nu uit de wetsgeschiedenis blijkt dat de cumulatie van beide sancties door de wetgever zelfs tot uitgangspunt is genomen. Mede gelet daarop meent de A-G dat sprake is van 'a sufficiently close connection, in substance and time' tussen beide procedures, zoals bedoeld in EHRM A en B tegen Noorwegen. Ook op die grond meent hij derhalve dat zich geen uitzonderlijke situatie voordoet die op gespannen voet staat met het aan artikel $68 \mathrm{Sr}$ ten grondslag liggende beginsel. Voor dit betoog valt onzes inziens zeker wat te zeggen, met name gelet op de omstandigheid dat de cumulatie van beide procedures voorzienbaar is en de procedures bovendien verschillende complementaire doelen dienen.

Het CBR heeft verder de bevoegdheid tot het opleggen van verscheidene maatregelen aan bestuurders van motorrijtuigen ten aanzien van wie een vermoeden van onvoldoende rijvaardigheid of geschiktheid bestaat. Zo kan het een Educatieve Maatregel Alcohol en Verkeer (hierna: EMA) opleggen indien een persoon weigert mee te werken aan een ademanalyse. Degene die een EMA krijgt opgelegd is verplicht hieraan zijn medewerking te verlenen. Hieronder valt ook het voldoen van de kosten van de EMA. Indien geen medewerking wordt verleend, besluit het CBR tot ongeldigverklaring van het rijbewijs. Het ne bis in idem-beginsel staat er niet aan in de weg dat het Openbaar Ministerie een strafvervolging start ter zake van hetzelfde feit. De EMA is namelijk een bestuurlijke maatregel die strekt tot bevordering van de rijvaardigheid of geschiktheid. Oplegging van een EMA vloeit voort uit het vermoeden dat de houder van een rijbewijs niet langer beschikt over de vereiste rijvaardigheid of geschiktheid. Een dergelijk vermoeden kan ook bestaan zonder strafrechtelijke vervolging of veroordeling. Gelet hierop is de oplegging van een EMA niet punitief van aard, zo oordeelde de Hoge Raad. ${ }^{45}$ Een

43. Vgl. in dit verband de overwegingen van het hof, dat overwoog dat het thans en het destijds opgelegde alcoholslotprogramma niet voor hetzelfde feitencomplex zijn opgelegd en vaststelde dat de verdachte thans strafrechtelijk wordt vervolgd voor het besturen van een auto die niet voorzien was van een alcoholslot, hetgeen een ander feit is dan het feit waarvoor de verdachte destijds een alcoholslotprogramma kreeg opgelegd. Het hof zocht het derhalve in de idem, terwijl zich de vraag naar de bis voordeed.

44. Zie HR 3 november 2015, ECLI:NL:HR:2015:3205, NJ 2016/72 m.nt Reijntjes.

45. HR 16 januari 2018, ECLI:NL:HR:2018:23, NJ 2018/64. 
beroep op het ne bis in idem-beginsel kan dan uiteraard niet meer slagen, nu geen sprake is van een ' $b i s$ '.

Deelname aan een geschiktheidsonderzoek naar de rijvaardigheid door het CBR wegens rijden onder invloed staat ook niet in de weg aan strafvervolging voor datzelfde feit. Een dergelijk onderzoek vindt plaats om te kunnen beoordelen of ongeldigverklaring van het rijbewijs is aangewezen. De kosten van het onderzoek, die kunnen oplopen tot ongeveer $€ 1.000$, komen voor rekening van de betrokkene. De verplichting tot deelname aan een geschiktheidsonderzoek wordt niet opgelegd op grond van het plegen van een strafbaar feit, ${ }^{46}$ al kan de verdenking van een dergelijk feit uiteraard wel aanleiding zijn voor dat onderzoek. 'Mede gelet daarop' is het onderzoek naar de rijvaardigheid of geschiktheid voor het besturen van motorrijtuigen een bestuurlijke maatregel die strekt tot bevordering van de verkeersveiligheid en die geen punitief karakter heeft, zo oordeelde de Hoge Raad. $^{47}$

Ten slotte staan we in het kader van de verkeersdelicten nog even stil bij de recidiveregeling van artikel $123 \mathrm{~b}$ lid 1 WVW 1994. Op grond van deze bepaling verliest een rijbewijs van rechtswege zijn geldigheid indien aan de in die bepaling gestelde voorwaarden is voldaan. Kort gezegd is dit het geval indien de verdachte reeds onherroepelijk is veroordeeld voor één van de feiten genoemd in artikel 123b lid 1 WVW 1994 in de vijf jaar voorafgaand aan het feit waarvoor hij op dat moment wordt vervolgd. Met het onherroepelijk worden van de tweede veroordeling wordt het rijbewijs automatisch ongeldig. In cassatie is gesteld dat dit strijdig is met het ne bis in idem-beginsel. De Hoge Raad gaat daar echter niet in mee en neemt daarbij in aanmerking dat de strafrechter bij de vervolging van het feit dat tot die tweede veroordeling leidt in het kader van de straftoemeting rekening kan houden met het gevolg dat door de regeling van artikel 123b WVW 1994 wordt verbonden aan de veroordeling indien deze onherroepelijk wordt. ${ }^{48}$

\subsection{Civielrechtelijke procedure}

Privaatrechtelijke maatregelen hebben naar algemeen wordt aangenomen geen punitief karakter, ${ }^{49}$ waardoor vragen in verband met samenloopperikelen zich minder

46. Net zomin als de ongeldigverklaring van een rijbewijs zelf (HR 3 november 2015, ECLI:NL:HR:2015:3205, NJ 2016/72 m.nt. Reijntjes).

47. HR 26 juni 2018, ECLI:NL:HR:2018:1014, NJ 2018/299.

48. HR 18 december 2018, ECLI:NL:HR:2018:2350, NJ 2019/75 m.nt. Reijntjes. A-G Spronken hanteert een andere benadering en betoogt in haar conclusie voor het arrest (ECLI:NL:PHR:2018:1090) dat het ongeldig worden van het rijbewijs een automatisch gevolg is van de strafrechtelijke veroordeling, 'zodat bezwaarlijk kan worden volgehouden dat de verdachte voor de tweede maal wordt vervolgd en bestraft voor het begaan van het in deze zaak tenlastegelegde feit.'

49. Zie F.C.W. de Graaf, Meervoudige aansprakelijkstelling. Een analyse van rechtsfiguren die aansprakelijkstelling voor meer dan één strafbaar feit normeren, Den Haag: Boom juridisch 2018, p. 247. Zij verwijst verder naar M.B. Beekhoven van Boezem, Doel en effect van dwangsom en lijfsdwang, Deventer: Kluwer 2003, p. 183; E.M. van der Heijden, 'Punitive damages en de calculerende schadeveroorzaker', NJB 2001, p. 1749-1756 en M.B. Beekhoven van Boezem, De dwangsom in het burgerlijk recht, Deventer: Kluwer 2006, p. 65 e.v. snel voordoen. In HR 13 november 2018, ECLI:NL:HR:2018:2017, Nf 2019/74 m.nt. Reijntjes (tweede cassatieronde ${ }^{50}$ ) was dat anders. In deze zaak werd de verdachte consecutief strafrechtelijk vervolgd voor het niet betalen van belastingaanslagen en het schenden van de fiscale inlichtingenplicht, nadat hij voor deze feiten reeds een jaar lang een civielrechtelijke lijfsdwang had ondergaan. De verdachte had een belastingschuld van ruim 250 miljoen gulden vanwege handel in verdovende middelen. De verdediging bepleitte met een beroep op de schending van het ne bis in idem-beginsel de niet-ontvankelijkheid van het Openbaar Ministerie. Het hof kwam aan de hand van een toetsing aan de Engel-criteria tot het oordeel dat sprake was van een schending van het beginsel en verklaarde het Openbaar Ministerie niet-ontvankelijk in de vervolging. Daarbij leek het hof met name gewicht toe te kennen aan de zwaarte van de maatregel, nu de civiele lijfsdwang in het onderhavige geval tot een jaar vrijheidsbeneming had geleid. Voorts overwoog het hof, en daarmee bezigde het hetzelfde criterium als de Hoge Raad in het Alcoholslotprogramma-arrest ${ }^{51}$, dat 'voor de betrokkene de gevolgen van het opleggen van de lijfsdwang en de van het instellen van een strafvervolging te verwachten strafrechtelijke sancties in hoge mate overeenkomen nu beide voor de betrokkene kunnen leiden tot een forse vrijheidsbeneming'. Het oordeel hield in cassatie echter wederom geen stand. De Hoge Raad overwoog, met een verwijzing naar de eerste cassatieronde, dat de opvatting dat na het starten van een civiele procedure geen ruimte meer bestaat om een strafsanctie toe te passen, niet juist is en vervolgde met de overweging dat de vergelijking met de uitzonderlijke situatie als bedoeld in het Alcoholslotprogramma-arrest niet opgaat: 'In dat verband geldt dat zich met betrekking tot de afstemming tussen enerzijds het civielrechtelijke traject en anderzijds het strafrechtelijke traject zoals dat in de onderhavige zaak aan de orde is, geen wezenlijke samenloopproblemen voordoen als in dat arrest bedoeld, mede omdat het in de rede ligt dat de strafrechter de toegepaste lijfsdwang als relevante omstandigheid bij de strafoplegging betrekt.'

\section{De rechtspraak nader beschouwd}

De oplettende lezer heeft het inmiddels vast geconstateerd: de raadsvrouw of -man die een beroep doet op het Alcoholslotprogramma-arrest vangt in cassatie bot. Om in de woorden van Reijntjes te spreken: 'Het is de Raad niet gelukt om iedereen ervan te overtuigen dat dit soort situaties werkelijk zo uitzonderlijk is dat zij niet veel vaker voorkomen. Dat de advocatuur zou proberen om

50. Voor de eerste ronde in cassatie zie HR 20 december 2011, ECLI:NL:HR:2011:BP4606, NJ 2012/27.

51. Zie HR 3 maart 2015, ECLI:NL:HR:2015:434, NJ 2015/256 m.nt. Keulen, r.o. 4.3.2. 
tot het gaatje te gaan mocht van haar worden verwacht; zij heeft aan die verwachting inmiddels meer dan voldaan. Maar ook de feitenrechter zag herhaaldelijk grond om het predicaat 'uitzonderlijk' toe te kennen aan gevallen waarvan de Raad vervolgens in cassatie moest vaststellen dat zij naar de termen van $N \mathcal{7} 2015 / 256$ toch eigenlijk maar heel gewoontjes zijn.' ${ }^{52}$ In alle hiervoor besproken arresten overwoog de Hoge Raad expliciet dat een vergelijking met de 'uitzonderlijke situatie' als bedoeld in het Alcoholslotprogramma-arrest niet opgaat. In deze paragraaf wordt de in paragraaf 3 besproken jurisprudentie tegen het licht gehouden. Wat maakt deze zaken anders dan het Alcoholslotprogramma-arrest? En hoe is deze jurisprudentie te plaatsen binnen ratio van het ne bis in idem-beginsel en de Europese kaders?

\subsection{De aard en de zwaarte van de maatregel}

Zoals in paragraaf 3 is uiteengezet, is voor de vraag of een tweede procedure strijdig is met het ne bis in idembeginsel van belang of deze procedure kan worden aangemerkt als een 'criminal charge'. $\mathrm{Nu}$ de Hoge Raad de term criminal charge in zijn arresten niet bezigt en evenmin expliciet toetst aan de Engel-criteria is niet onmiddellijk inzichtelijk hoe afweging tussen de verschillende criteria in een concreet geval plaatsvindt en wat maakt dat de wijzer naar de ene of de andere kant uitslaat. De Hoge Raad lijkt in het verband van een criminal charge in de meeste gevallen met name gewicht toe te kennen aan de aard van de maatregel. Zo heeft hij geoordeeld dat een EMA en een geschiktheidsonderzoek beide bestuurlijke maatregelen zijn die tot doel hebben de algehele verkeersveiligheid te bevorderen. Gelet daarop zijn ze niet punitief van aard. Ditzelfde geldt voor de ongeldigverklaring van het rijbewijs. Hoven komen daarentegen met name op grond van de zwaarte van de maatregel nogal eens tot de conclusie dat een maatregel moet worden aangemerkt als criminal charge. ${ }^{53}$ Zo overwoog het hof in het zojuist besproken Civiele lijfsdwang-arrest expliciet dat de gevolgen voor de betrokkene bij de lijfsdwang en de ingestelde strafvervolging in hoge mate overeenkomen, nu beide kunnen leiden tot een forse vrijheidsbeneming van aanzienlijke duur. Daarmee paste het hof eenzelfde redenering toe als de Hoge Raad in het Alcoholslotprogramma-arrest, maar het oordeel hield in cassatie toch geen stand. Kennelijk hechtte de Hoge Raad meer waarde aan de aard van de maatregel, die ertoe strekt een belastingschuld te kunnen verhalen wanneer de belastingschuldige weigert zijn belastingschuld te voldoen, terwijl hij wel beschikt over vermogensbestanddelen of inkomen. Het is een uiterste pressiemiddel dat behoedzaam dient te worden toegepast, gelet op de ingrijpendheid van de maatregel, maar het is naar zijn aard geen straf.

52. In zijn annotatie bij NJ 2019/74.

53. Zie, naast de in deze bijdrage besproken lijfsdwang, voorts bijvoorbeeld HR 12 december 2017, ECLI:NL:HR:2017:3122, NJ 2018/94 en HR 12 juni 2018, ECLI:NL:HR:2018:901, NJ 2018/388, beide m.nt. Reijntjes. Ook deze oordelen hielden in cassatie geen stand.
Er zijn wat ons betreft goede redenen om de aard van de maatregel een groot gewicht in de schaal te laten leggen bij de vraag of sprake is van een criminal charge in de zin van artikel 6 EVRM. Bestuurs- en civielrechtelijke maatregelen enerzijds en strafrechtelijke sancties anderzijds dienen nu eenmaal vaak andere (legitieme) doelen en soms zijn op één gedraging verschillende reacties vereist voor een effectieve rechtshandhaving. ${ }^{54}$ Dat deze maatregelen relatief verstrekkende gevolgen kunnen hebben, ${ }^{55}$ maakt dat niet anders. Het is zeer wel invoelbaar dat de betrokkene in kwestie een dergelijke combinatie van maatregelen zal kunnen ervaren als een 'dubbele straf', maar wanneer dat argument doorslaggevend zou zijn, zou dat ook het einde betekenen van bijvoorbeeld de ontnemingsmaatregel of oplegging van tbs naast een strafrechtelijke veroordeling. Dergelijke maatregelen dienen immers ook andere doelen en zijn naar hun aard niet punitief, maar dat laat onverlet dat deze maatregelen wel degelijk kunnen worden ervaren als een straf.

\subsection{De rechtspraak in het licht van de ratio van} het ne bis in idem-beginsel

Toch is het bezien vanuit de materiële grondgedachte van het ne bis in idem-beginsel van belang wel oog te hebben voor de gevolgen en zwaarte van een maatregel en is het in sommige gevallen te gemakkelijk om te zeggen dat de aard van de maatregel niet punitief is.

Zowel het alcoholslotprogramma als bijvoorbeeld de civiele lijfsdwang zijn naar hun aard niet punitief, maar voor beide maatregelen geldt ook dat de gevolgen voor de betrokkene in kwestie niet mis zijn. Uit de overwegingen van de Hoge Raad in het Alcoholslotprogrammaarrest blijkt dat voor het oordeel dat sprake was van strijd met het ne bis in idem-beginsel van groot belang was dat de gevolgen van het alcoholslotprogramma en de te verwachten strafrechtelijke sancties sterk gelijkend waren. Toch kan worden betoogd dat dat niet anders was bij de civiele lijfsdwang. Wat maakt nu dat de Hoge Raad in de ene zaak wel 'wezenlijke samenloopproblemen' aannam en in de andere zaak niet? Volgens de Hoge Raad was dit mede omdat in de rede ligt dat 'de strafrechter de toegepaste lijfsdwang als relevante omstandigheid bij de strafoplegging betrekt'. Een cruciale overweging. Met deze overweging laat de Hoge Raad namelijk zien oog te hebben voor het risico dat de overheidsreactie in dit geval de facto onevenredig zou kunnen uitvallen. Ondanks dat de civiele lijfsdwang naar haar aard geen punitieve sanctie is, leidde het in dit geval wel tot maar liefst een jaar vrijheidsbeneming. Door de eerder opgelegde maatregel als relevante omstandigheid bij de strafoplegging te betrekken kan recht worden gedaan aan de materiële ratio van het ne bis

54. Vgl. J. de Hullu, Materieel strafrecht, Deventer: Wolters Kluwer 2018, p. 562.

55. Vgl. bijvoorbeeld voor een opgelegde randvoorwaardenkorting HR 14 februari 2017, ECLI:NL:HR:2017:241, NJ 2017/289; HR 12 december 2017, ECLI:NL:HR:2017:3122, NJ 2018/94 voor een last onder dwangsom en HR 12 juni 2018, ECLI:NL:HR:2018:901, NJ 2018/388 voor de schorsing van een vergunning, alle m.nt. Reijntjes. 
in idem-beginsel, dat immers tot doel heeft om in het kader van de proportionaliteit van de straf meervoudige bestraffing te voorkomen.

Een soortgelijke redenering zagen we bij het arrest inzake de recidiveregeling van artikel $123 \mathrm{~b}$ WVW 1994. ${ }^{56}$ De Hoge Raad overwoog in dat verband dat de strafrechter bij de vervolging van het feit dat tot een tweede vervolging in de zin van die bepaling leidt, in het kader van de straftoemeting rekening kan houden met het gevolg dat door artikel 123b WVW 1994 wordt verbonden aan de veroordeling indien deze onherroepelijk wordt. De rechter die in de strafprocedure oordeelt, kent dit gevolg en kan dit gegeven verdisconteren in de straf - zoals het hof ook uitdrukkelijk had gedaan.

\subsection{De rechtspraak bezien vanuit Europese context}

Ook in de Europese jurisprudentie ligt de nadruk vooral op het voorkomen van onevenredige bestraffing wanneer twee overheidsreacties volgen op één feit. Het is, zoals bleek uit paragrafen 3.2 en 3.3, op grond van Europese jurisprudentie mogelijk om twee procedures te beschouwen als één procedure, dat wil zeggen als één reactie op bepaald laakbaar gedrag, indien is voldaan aan de in deze jurisprudentie ontwikkelde factoren. Daarbij is volgens het EHRM vooral van groot belang dat die reactie als geheel niet disproportioneel uitvalt: 'and, above all, whether the sanction imposed in the proceedings which become final first is taken into account in those which become final last. ${ }^{57}$ Het HvJ EU overweegt soortgelijk dat van belang is dat de procedures onderling worden afgestemd en dat de zwaarte van het geheel van de opgelegde sancties is beperkt tot het strikt noodzakelijke in verhouding tot de ernst van het delict. ${ }^{58}$ Zowel bij de recidiveregeling van artikel 123b WVW 1994 als de civiele lijfsdwang overwoog de Hoge Raad soortgelijk dat de strafrechter rekening kan houden met de maatregelen die reeds zijn opgelegd in de eerdere procedure. Daardoor valt de overheidsreactie als geheel niet disproportioneel uit. Hoewel de Hoge Raad niet zo ver gaat door te stellen dat beide procedures kunnen worden beschouwd als één reactie op bepaald gedrag en ook niet expliciet toetst aan vorenbedoelde Europese rechtspraak, ${ }^{59}$ lijkt het er sterk op dat de Hoge Raad wel toepassing heeft willen geven aan de ruimte die Europese hoven bieden bij de samenloop van procedures, waarbij, wij herhalen het nog maar eens, vooral van belang is dat de overheidsreactie als geheel niet disproportioneel uitvalt voor de betrokkene.

\section{Afronding}

De grenzen tot waar de bescherming van het ne bis in idem-beginsel reikt, zijn en blijven voer voor discussie. Feitenrechters lijken soms te worstelen met de toepassing van het beginsel. Uit de in dit artikel weergegeven rechtspraak volgt dat de Hoge Raad veel waarde lijkt te hechten aan de aard van de maatregel bij de vraag of sprake is van een punitieve vervolging of sanctie en aldus van een 'bis'. De in paragraaf 5 geboden analyse laat verder zien dat de Hoge Raad het in bepaalde gevallen van belang acht dat de strafrechter de eerder opgelegde maatregel als relevante omstandigheid bij de strafoplegging betrekt. Met de hier voorgestane weg ondervangt de Hoge Raad mogelijke problemen die kunnen rijzen in het kader van de materiële grondgedachte van het ne bis in idem-beginsel. Daarnaast concluderen wij dat deze benadering in overeenstemming is met de jurisprudentie van zowel het EHRM als het HvJ EU. De nadruk lijkt aldus, zowel in nationale als in Europese context, (steeds meer) te liggen op evenredige bestraffing bij cumulatie van procedures.

Wat leert dit alles ons voor de praktijk? Allereerst moge inmiddels duidelijk zijn dat een beroep op het Alcoholslotprogramma-arrest naar verwachting weinig zal opleveren. Uit de geboden analyse volgt immers dat de Hoge Raad de deur naar de uitzonderingspositie van het Alcoholslotprogramma-arrest (vooralsnog) dichthoudt voor andere gevallen. Het ligt voor de verdediging veel meer voor de hand om in het kader van een strafmaatverweer te wijzen op de maatregel die in een eerdere finale procedure is opgelegd en te verzoeken dit als relevante omstandigheid bij de strafoplegging te betrekken. Het is namelijk de taak van de feitenrechter om in het kader van de straftoemeting, in overeenstemming met de ratio van het ne bis in idem-beginsel, zorg te dragen voor een proportionele overheidsreactie.
56. Een dergelijke overweging keert overigens ook terug in bijv. HR 14 februari 2017, ECLI:NL:HR:2017:241, NJ 2017/289 en HR 12 december 2017, ECLI:NL:HR:2017:3122, NJ 2018/94, beide m.nt. Reijntjes. Het punt is voor de Hoge Raad kennelijk - en wat ons betreft in het geheel niet onterecht - van groot belang.

57. EHRM 15 november 2016, nrs. 24130/11 and 29758/11 ( $A$ en B/ Noorwegen), § 132 .

58. HvJ EU 20 maart 2018, ECLI:EU:C:2018:197, C-524/15 (Menci), § 63.

59. $\mathrm{Vgl}$. de conclusie van A-G Machielse, die wel expliciet toetst aan $A$ en $B /$ Noorwegen en tot de conclusie komt dat de civiele lijfsdwang en de strafvervolging voldoende 'connected' zijn (punt $3.16 \mathrm{t} / \mathrm{m} 3.19$ ) voor HR 13 november 2018, ECLI:NL:HR:2018:2017, NJ 2019/74 m.nt. Reijntjes. 